\title{
Cohort Study of Bovine Malignant Catarrhal Fever in Cavery Delta Districts of Tamil Nadu
}

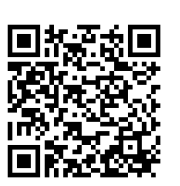

\author{
Krishna Kumar $\mathbf{S}^{1 *}$, Richa Sood ${ }^{2}$, Selvaraj $\mathbf{P}^{1}$, Jayalakshmi $\mathrm{K}^{1}$ and Ranjith Kumar $\mathbf{M}^{1}$ \\ ${ }^{1}$ Department of Veterinary Medicine, Veterinary College and Research Institute, India \\ ${ }^{2}$ Indian Council of Agricultural Research, India
}

Submission: August 01, 2019; Published: August 29, 2019

"Corresponding author: Krishna Kumar S, Department of Veterinary Medicine, Veterinary College and Research Institute, India

\begin{abstract}
Malignant catarrhal fever (MCF) is a Sheep derived lethal viral disease mainly affecting Bovidae, cervids and other ruminant species. Alcelaphine herpesvirus 1 (AlHV-1) and ovine herpesvirus 2 (OvHV-2) are the two most widely prevalent causative organisms for tropical MCF. Wildebeest associated MCF (WA-MCF) in cattle is prevalent in African sub-continent. The OvHV-2 is prevalent in domestic sheep as a sub-clinical infection and causes sheep associated MCF (SA-MCF) in susceptible ruminants. In India, the detection of cases of SA-MCF in cattle and OvHV-2 infection in sheep during the last decade has established the presence of the virus in native sheep of the country. The present study documents the presence of bovine MCF in Cavery delta districts of Tamilnadu.
\end{abstract}

Keywords: Bovine; Malignant catarrhal fever; Ovine origin; Tamilnadu

\section{Introduction}

Malignant catarrhal fever (MCF) is usually a fatal disease of bovids, cervids and certain other susceptible ruminant species. MCF primarily affects the lymphoid organs, respiratory and alimentary tracts which is characterized by high fever, in appetence, ocular and nasal discharge, kerato-conjunctivitis with corneal opacity and enlargement of peripheral lymph nodes. Death may occur within few days or several weeks after the onset of clinical signs [1]. In the regions of African sub-continent, AlHV-1 naturally infects wildebeest and causes wildebeest associated MCF (WA-MCF) in cattle while the OvHV2 infects domestic sheep as a sub-clinical infection and causes sheep associated MCF (SA-MCF) in susceptible cattle in tropical countries. Virus are excreted through nasal and ocular secretions mainly, but also reported in faeces and semen. Close contact of susceptible species with sheep may result in SA -MCF.

\section{Materials and methods}

An 18 months old crossbred Holstein Friesian heifer was referred to the Large animal Medicine Referral clinic of the Veterinary College and Research Institute, Orathanadu, Tamilnadu. India. Upon Clinical examination it had pyrexia (41.5 ${ }^{\circ} \mathrm{C}$ ), highly enlarged pre scapular lymph nodes and bilateral corneal opacity. Systemic examination was unremarkable. Clinical samples like whole blood in EDTA, clotted blood in serum activator tubes and peripheral blood smears were collected and analyzed. Clinical samples were also collected from co - habituating sheep population where the affected cattle were reared. Complete blood count, biochemical tests and blood protozoan screening were done. Data like geolocation, season and farming details were collected and analyzed (Figure 1).

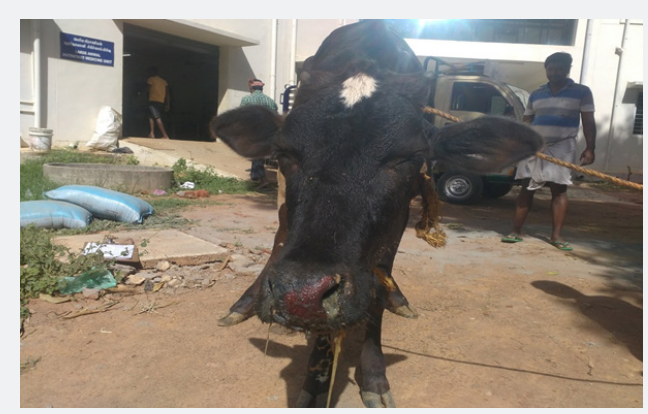

Figure 1: Muco purulent nasal discharge with superficial necrosis of nasal mucosa. 
A $5 \mathrm{ml}$ of blood was collected aseptically from jugular vein from both Cattle and Sheep (reared near the affected cow) and kept in refrigerated temperature until processing.

\section{Separation of sera}

Clotted blood was collected in clot activator tubes and kept in slanting position for 15 minutes. Serum was separated by centrifuging the clotted blood at $3000 \mathrm{rpm}$ for $10 \mathrm{~min}$ and sera were inactivated by keeping it at $56^{\circ} \mathrm{C}$ for $30 \mathrm{~min}$.

\section{Separation of pbl and dna isolation}

Leucocytes were separated as per the procedure adopted earlier. $2 \mathrm{ml}$ of whole blood collected in di potassium EDTA and tube was centrifuged at $1000 \mathrm{rpm}$ for $20 \mathrm{~min}$. The buffy coat was collected, and erythrocyte lysis buffer was added at a ratio of $1: 2$. After keeping for $10 \mathrm{~min}$ at room temperature, centrifuged at $2000 \mathrm{rpm}$ for $10 \mathrm{~min}$. The supernatant was decanted, and the process was repeated till complete lysis of RBC. Finally, the pellet was re suspended with $2 \mathrm{ml}$ of sterile PBS and stored at $-86^{\circ} \mathrm{C}$ until analysis. Hemi-nested PCR were performed as described earlier [2].

\section{Results and Discussion}

The affected cow was found to have head and eye form of $\mathrm{MCF}$ as it had signs like pyrexia $\left(41.5^{\circ} \mathrm{C}\right)$, anorexia, enlargement of lymph node, progressive corneal opacity and necrosis of nasal mucosa. Upon history and clinical signs, the cow was tentatively diagnosed to have MCF. As blood protozoal screen was negative, hemoparasitic disease was ruled out. The animal was treated with antibiotics, anti-inflammatory drugs and fluid therapies. On third day of the clinical course, the animal died. The farmer was unwilling for a postmortem. In previous study, progression of corneal edema correlated well with disease outcome, and that non improvement of uveitis was considered as a bad prognostic sign [3]. The same was observed in this case study also. Complete blood count showed no major abnormalities (Table 1). Total protein was 5.7 with a globulin value of 3.4 (Table 2). From the PCR tests, the animal was confirmed for ovHV-2 in whole blood sample and the six samples from sheep were negative for MCF by outer and nested Polymerase chain reaction (Figure 2).

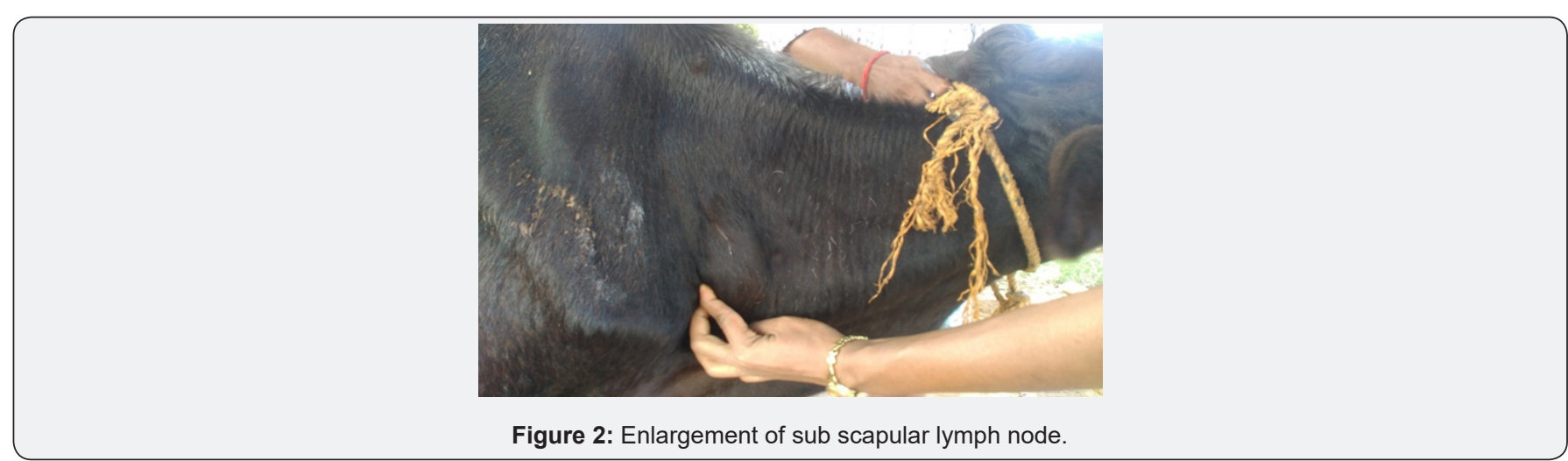

Table 1: Complete blood count of MCF positive heifer.

\begin{tabular}{|c|c|c|}
\hline S. No & Parameter & Value \\
\hline 1. & Hemoglobin & $6.3 \mathrm{mg} / \mathrm{dl}$ \\
\hline 2. & RBC & $35 \%$ \\
\hline 3. & PCV & $4000 /$ cumm \\
\hline 4. & WBC & 40 \\
\hline 5. & Neutrophil & 58 \\
\hline 6. & Lymphocyte & 1 \\
\hline 7. & Monocyte & 1 \\
\hline 8. & Esinophil & \\
\hline
\end{tabular}

Table 2: Biochemical value of MCF positive heifer.

\begin{tabular}{|c|c|c|}
\hline S. No & Parameter & Value \\
\hline 1. & Total Protein & 5.7 \\
\hline 2. & Albumin & 2.3 \\
\hline 3. & Globulin & 3.4 \\
\hline
\end{tabular}


In the current study, the availability of plenty of paddy field attracts migratory sheep populations and then pose threat to the Bovidae. Young Sheep (9-12 months) generally have higher prevalence of $\mathrm{MCF}$ and it spreads the disease to the neighboring susceptible population. Samples from sheep showed negative for MCF since Infectious OvHV-2 is present in ovine nasal secretions but appears to be difficult to isolate from this source, since the period of virus shedding is short for any given animal $[4,5]$.
Sheep could act as a potential source of infection for the clinically susceptible species and to the remaining reservoir population $[6,7]$. India has large susceptible population species and mixed livestock farming system practiced will increases the chances of close contact of carrier animals like sheep and goat with susceptible animals while co-habituating or during community grazing. The level of total protein along with higher globulin levels indicates the chronic nature of the disease (Figure 3).

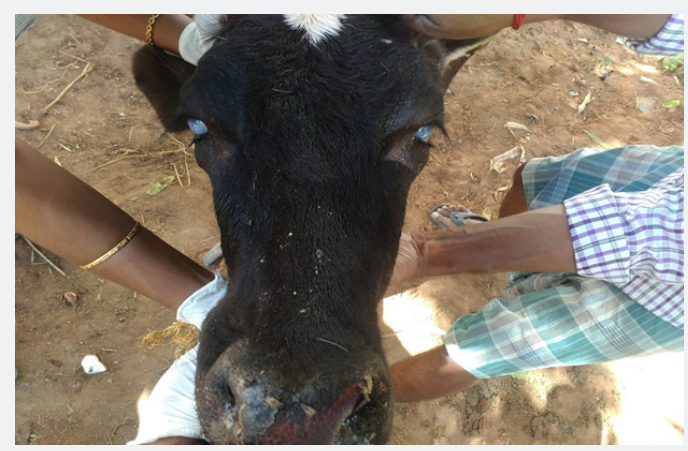

Figure 3: Bilateral Corneal opacity with peeled of muzzle mucosa.

\section{Conclusion}

SA-MCF is pandemic in nature of its distribution and has shown its presence in India also. SA-MCF is an emerging and an economically important disease of cattle and is particularly significant in the Indian context where mixed farming is advocated commonly. Due to its sporadic nature and overlapping clinical signs with hemoprotozoan diseases, the disease is underestimated among veterinarians, researchers and policy makers in India. With development of PCR based assays and their improved versions make easier to know about the epidemiology of MCF in India. Sero and molecular surveillance of this disease will provide the epidemiology of MCF and its impact on livestock health and productivity. Avoiding of grazing both cattle and Sheep in the same place will reduce the epidemic of MCF in India.

\section{Acknowledgement}

1. The authors expressed their sincere thanks to Tamilnadu Veterinary and Animal Sciences University, Chennai -51,

2. The Director, National Institute of High Security Animal Diseases, Indian Council of Agricultural Research, Anand Nagar, Bhopal- 462022 (MP), INDIA.

\section{References}

1. Russell GC, Stewart JP, Haig DM (2009) Malignant catarrhal fever: a review. Vet J 179(3): 324-335.

2. Sood R, Khandia R, Bhatia S, Hemadri D, Kumar M, et al. (2014) Detection and molecular characterization of naturally transmitted sheep associated malignant catarrhal fever in cattle in India. Trop Anim Health Prod 46(6): 1037-1043.

3. Premkrishnan GN, Sood R, Hemadri D, Chanu KhV, Khandia R, et al. (2015) Cross-sectional study indicates nearly a quarter of sheep population in Karnataka state of India is infected with ovine herpesvirus 2. Virusdisease 26(3): 180-188.

4. Li H, O'Toole D, Kim O, Oaks JL, Crawford TB (2005) Malignant catarrhal fever-like disease in sheep after intranasal inoculation with ovine herpesvirus-2. J Vet Diagn Invest 17: 171-175.

5. Zemljic T, Pot SA, Haessig M, Spiess BM (2012) Clinical ocular findings in cows with malignant catarrhal fever: ocular disease progression and outcome in 25 cases 2007-2010. Vet Ophthalmol 15(1): 46-52.

6. Banumathi N, Sood R, Patil SS, Subramanian M, Pradhan HK (2008) Genomic detection of Ovine herpes virus-2 in sheep and goat in states of southern India. Ind J Anim Sci 78(1): 13-16.

7. Sood R, Hemadri D, Bhatia S (2013) Sheep associated malignant catarrhal fever: an emerging disease of bovids in India. Indian J Virol 24(3): 321-331. 


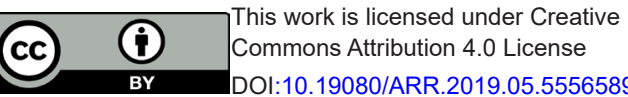

\section{Your next submission with Juniper Publishers} will reach you the below assets

- Quality Editorial service

- Swift Peer Review

- Reprints availability

- E-prints Service

- Manuscript Podcast for convenient understanding

- Global attainment for your research

- Manuscript accessibility in different formats ( Pdf, E-pub, Full Text, Audio)

- Unceasing customer service

Track the below URL for one-step submission https://juniperpublishers.com/online-submission.php 